\title{
Genetic Improvement through Selection of Different Stevia rebaudiana Genotypes
}

\author{
Nader R. Abdelsalam ${ }^{1}$, Asmaa S. M. Haraz ${ }^{2}$, Haraz, Ahmed E.Khalid ${ }^{1}$, Magdy S. H.Saleh²,
} Ahmed E. A.Elsheikh ${ }^{2}$

\begin{abstract}
The present investigation was carried out at Faculty of Agriculture Saba Basha, Alexandria University and Sabahia Agricultural Research Station during two succesive seasons 2013-2014 and 2014-2015 from nature population of Stevia (Stevia rebaudiana Bertoni) in order to study the genetic improvement through selection for different Stevia genotypes. Ninteen stevia accessions were collected from healthy plants of nature population and selected randomly. The data showed high significant variations between all tested genotypes and there is high genetic diversity between these genotypes and this might be, due to the open pollination for these genotypes for several years and theses genotypes could used in the future in breeding programme. Also, it can conculad that the difference in rebaudioside $A$ due to the difference in the genetic and the negatively correlation between stevioside and rebaudioside- $A$. can be partially explained by the biosynthetic relationships between the individual glycosides because stevioside is the substrate for the synthesis of rebaudioside $A$.
\end{abstract}

Key words: Stevia rebaudiana, selection, HPLC, RAPD-PCR

\section{INTRODUCTION}

Stevia rebaudiana Berttoni is a genus of about 200 species of herbs and shrubs in the sunflower family (Asteraceae), the most valuable tropical medicinal plant, It's a natural sweet ner herb native of northeastern Paraguay and today it is cultivated around the world (Savita et al., 2004). Stevia is diploid plant, having 11 pairs of chromosome (Frederico et al., 1996) with critical day length of 13 hours (Zaidan et al., 1980). Stevia rebaudiana Berttoni grows up to $1 \mathrm{~m}$ tall (Mishra et al., 2010). The plant is a perennial herb with an extensive root system and brittle stems producing small, elliptic leaves. Medicinal plants are of great importance to the health of individuals and communities. The medicinal value of these plants comes from its chemical substances that produce a definite physiological action on the human body.Alkaloids, tannins and polyphenols are important bioactive constituents of Stevia (Edeoga et al., 2005).

\footnotetext{
${ }^{1}$ Agricultural Botany Department, Faculty of Agriculture Saba-Bacha, Alexandria University, 22 Tag El-Roasa St. Saba Pacha, Boulkly P.O. Box: 21531.

${ }^{2}$ Breeding and Genetic Department, Sugar Crops Institute, Agricultural Research Center

(corresponding author: nader.wheat@yahoo.com)

Received February 14, 2016, Accepted February28, 2016
}

S. rebaudiana (commonly referred to as honey leaf, candy leaf and sweet leaf) is rich in terpenes and flavonoids. The basic raw material for the production of stevioside is the leaves of the stevia plant. The leaves of stevia naturally contain a mixture of 8 sweet diterpene glycosides: C, D stevioside, steviolbioside, rebaudiosides (A, B, and E) and dulcoside A (Geuns, 2003). Stevioside, one of the Stevia glycosides, is about 300 times sweeter than saccharoseit is present with an average of $4-20 \%$ in the dry matter of the plant leaves, which primarily depends on cultivar characteristics of plants and basic agricultural techniques (Geuns 2000) and can be particularly beneficial to those suffering from obesity, diabetes mellitus, heart disease and dental caries (Ghanta et al., 2007). Dry leaves of stevia are sweeter approximately 10 to 15 times than sucrose (Raymond, 2009) while glycemic index is zero, so it is sweetener with no caloric value (Kroyer, 2010; Seema, 2010; Puri et al., 2011) and with proven non-toxic effect on human health (Barriocanal et al., 2008).

The leaves of stevia are used as a food additive and a sweetener in food products, a green powder obtained by grinding of dried green leaves (Mishra et al., 2010), a white powder obtained by depigmentation process of green powder (Brandle et al., 1992) and a solution obtained by different extraction methods of stevioside and rebaudioside A from green powder (Abou-Arab et al., 2010). Stevia leaf extract shows high level of antioxidant activity, as well as, the variety of phytochemicals such as phenolic compounds, which is directly associated with the removal of free electrons and superoxide radicals (Thomas and Glade, 2010; Benzie and Watchel-Galor, 2011). Therefore, stevia plant has significant potential for use as a natural antioxidant (Shukla et al., 2009; Ahmad et al., 2010; Kim et al., 2011). In recent years, stevia products find widespread use in the food industry (Savita et al., 2004; Midmore and Rank, 2006). Steviol glycosides are used as a sweetener in many industrial foods, such as soft drinks or fruit juices (Goyal et al., 2010), desserts, sauces, delicacies, sweet corn, bread, biscuits and a 
table sweetener. Stevia diterpene replace sucrose in: cereals (muesli), pickles, yoghurt (Amzad-Hossain et al., 2010), candy (Goyal et al., 2010), soybeans and soy sauce (Amzad-Hossain et al., 2010) and seafood (Goyal et al., 2010).

Randomly amplified polymorphic DNA (RAPD) analysis is a polymerase chain reaction (PCR) based on procedure of (Williams et al. 1990). RAPD markers are usually dominant, with polymorphisms between individual plants indicated by the presence or absence of a particular rapd fragment. RAPDs have widely been used for map construction and linkage analysis because of their simplicity and relatively low cost (Reiter et al. 1992). As part of laying the foundation for molecular breeding, RAPD markers used to study the genetic polymorphic aiming to construct a genetic map of the stevia genome (Banerjee et al., 1999). Thiyagarajan and Venkatachalam (2015) reported that the genomic DNA polymorphism and phytochemical variation of Stevia rebaudiana Bertoniwas investigated by RAPD-PCR for initial PCR screening, about hundredoligo-nucleotide primers were used to amplify the genomic DNA from three accessions of $S$. rebaudiana (L1 to L3).

HPLC used to analyze stevioside extracted from the leaf and callus of Stevia rebaudiana Mahmud et al. (2014). The stevioside in each sample were analyzed by comparing their retention times with those of the standards. They maintained that the retention time (RT) of stevioside for leaves was found 14.96 and for callus 13.81 mins. The percentage of stevioside content from leaves and callus was $12.19 \%$ and $12.62 \%$ respectively. This investigation was carried out to study the following aspects, morphological characteristics such as plant height $(\mathrm{cm})$, number of secondary branches per plant, fresh weight of leaves (gm/plant), dry weight of leaves (gm/plant), fresh weight of stems (gm/plant) and dry weight of stems (gm/plant),on Stevia plants, calculate the content of Stevioside and Rebaudioside A and identify the genetic polymorphism in stevia rebaudiana population via RAPD-PCR.

\section{MATERIALS AND METHODS}

The present investigation was carried out at Faculty of Agriculture Saba Basha, Alexandria University and Sabahia Agricultural Research Station during two succesive seasons 2013-2014 and 2014-2015 upon nature population of Stevia (Stevia rebaudiana Bertoni). Ninteen stevia accessions (Stevia rebaudiana Bertoni) were collected from healthy plants of nature population and selected randomly, plants were multiplied vegetatively through micro-cuttings in of $10: 15 \mathrm{~cm}$ with 3-4 leaves. The micro-cutting propagation was carried out by cutting the young apical shoots (YAS) of matured stevia accessions towards the apex. Five plants per an accession were made from each genotype. The excised cuttings were dipped into Indole-3-buutyric acid (IBA) for 15 minutes in order to allow the auxin get absorbed into the cut stem through the xylem, and inorder to stimulate the cuttings to sprout roots in a mist chamber. Upon rooting the young plants were transferred to a nursery section in small polyethylene bags under a shade and were made to remain there for two weeks. This stage was necessary to harden the young growing plants. The soil type used in this experiment was a mixture of sand and loam; all the plants were subjected to the same conditions of growth and made to develop under the same climatic condition in Sabahia Agricultural Research Station. After two weeks young plants were transferred to a larger polyethylene bags and finally taken to field. When the plants became three months old they were evaluated on the field and subjected to various analyses.

\section{Morphological variations of Stevia genotypes:}

Plant height $(\mathrm{cm})$ was expressed in $\mathrm{cm}$, as the ratio between the measurements from the soil surface to the highest point of the plant, obtained from five plants of each plot; number of secondary branches, calculated as the mean number of secondary branches per plant (BP); fresh weight of leaves (g) calculated as yield of fresh matter (FM) in $\mathrm{g} /$ plant; dry weight of leaves ( $\mathrm{g}$ ) calculated as yield of dry matter (DM) in g/plant; fresh weight of stems $(\mathrm{g})$ calculated as yield of fresh matter (FM) and expressed in g/plant weighing five plants per plot; dry weight of stems (g): yield of dry matter (DM) was expressed in $\mathrm{g} / \mathrm{plant}$; moisture contents (\%): calculated as (fresh weight- dry weight)/Fresh weight*100

\section{Extraction and estimation of Stevia sweeteners:}

Stevia leaves were dried in an electric oven (E. Schulz \& Co. Inh. Franz. Skorezewsh $\mathrm{KG}$ at $50^{\circ} \mathrm{C}$ ). Stevia sweeteners were obtained from Stevia International Company for Agra industrial Projects (SKAP). Stevioside standard preparation was carried out according to Nishiyama et al. (1992) as follows: dried Leaves (10 g leaves of Stevia rebaudiana Bertoni obtained from Sigma) were extracted by soaking leaves in 1.0 liter of water nearly boiling $\left(85^{\circ} \mathrm{C}\right)$ for 30 minutes. The resulting liquid fraction was separated by buchner filtration and the residue was washed with an additional volume of hot water $(50 \mathrm{ml})$. The aqueous solution was concentrated by lyophyilization (Edwards Model EF03, England) to be $50 \mathrm{ml}$ and defatted by ethyl acetate then extraction with isobutyl alcohol $(150 \mathrm{ml})$. The aqueous phase was discarded and the organic solution was evaporated by rotary evaporator (Type 349 , James Jobling and Co. Ltd. England) at $70^{\circ} \mathrm{C}$ until drying was obtained. The dried extract was dissolved in 
hot methanol $(100 \mathrm{ml})$ and kept over night to crystallize. The crystals were separated by filtration and redissolved again in boiling methanol $(50 \mathrm{ml})$. This solution was clarified with active charcoal (B.D.H. Laboratory Chemicals Division. The procedure was repeated three times until the formation of colorless crystals was observed. The pure solution of the stevioside prepared ( $\mathrm{pH}$ of 9) was subjected to HPLC.At the same time an authentic pure stevioside was obtained from $\mathrm{N}$ u Naturals Inc. U.S.A.

Extraction of Stevia sweeteners from leaves was carried out by $0.5 \mathrm{gm}$ of dry stevia leaves was ground and dissolved in $0.5 \mathrm{ml}$ methanol and put in shaking and heating for 30 minutes at $70^{\circ} \mathrm{C}$ then kept in room temperature for cooling then abukhner funnel was used for filtiration using Afilter paper one time after that we used Activated charcoal for filtration another time finally it were kept the filtrate frozen until analysis. Stevia (Stevia rebaudiana Bertoni) leaves extract was separated and identified on HPLC as follows: Stevioside and other sweet components standard as prepared above were filtered through a millipore membrane (13 $\mathrm{mm}$. diameter, $0.5 \mu \mathrm{m}$ pore size) were subjected for determination by chromatography with stevioside standard as internal standard. Different extracts of Stevia leaves were injected for chromatography Acetonitrile with HPLC grade (Fisons Co. England) was used in this study as mobile phase. HPLC separation was carried out on $210 \mathrm{~nm}$ (Agilent 1200PDA detector); Eclipse plus C18 column $(3.5 \mu \mathrm{m}$ $4.6 \times 250 \mathrm{~mm})$; linear gradient over $20 \mathrm{~min}(84: 55 \%$ $\mathrm{CH} 3 \mathrm{CN}$ in $\mathrm{H} 2 \mathrm{O} / 0.1 \% \mathrm{TFA}$ ); flow rate $2.0 \mathrm{~mL} / \mathrm{min}$. Injection volume: $70 \mu \mathrm{l}$ at ambient temperature $\left(25^{\circ} \mathrm{C}\right)$. All the conditions used were according to Makapugay et al., (1984). For each samples identification quantification and the retention time were as described by Makapugay et al., (1984). Area under each peak was used to calculate the percent of each compound.

\section{Random amplified polymorphic DNAs (RAPD) analysis of Stevia genotypes:}

DNA is amplified by the polymerase chain reaction (PCR) using arbitrary short (10 nucleotides) primers (Williams et al., 1990). RAPD has become an important technique for population genetic studies since the amplified products provide random representation of both coding and non-coding regions across the whole genome. DNA was extracted following (Murray and Thompson, 1980) with minor amendments as follow. 50 mg samples of of Leaves of Stevia (Stevia rebaudiana Bertoni) material was ground with pestle and motor in $1 \mathrm{ml} 2 \mathrm{X}$ CTAB (1M tris (ph8), 0.5M EDTA (ph8), 5M $\mathrm{NaCl}, 20 \mathrm{gm}$ CTAB (Cetyl-tetramethyl ammonium bromide) in $1000 \mathrm{ml}$ ) containing $25 \mu 1$ mercaptoethanol, $10 \mathrm{mg}$ polyvinyl pyrolidine (pvp). About $750 \mu \mathrm{l}$ well ground paste was taken in to $1.5 \mathrm{ml}$ labeled eppendorf tube. Tubes were inverted gently to mix the ingredients incubated at $65^{\circ} \mathrm{C}$ for 45 minutes in water bath and centrifuged $12,000 \mathrm{rpm}$ for 10 minutes. Then in new eppendorf tube taken $700 \mu \mathrm{l}$ supernetant, $350 \mu 11 \mathrm{M}$ tris (ph 8), 350 $\mu$ l chloroform: isoamyle alcohol(24:1), $5 \mu 1$ proteinase $\mathrm{K}$. Tubes were inverted gently to mix the ingredients and centrifuged $12,000 \mathrm{rpm} 10$ minutes. About $400 \mu$ l supernatant were taken carefully in to new labeled eppendorf tube, $400 \mu$ l chloroform: isoamyle alcohol (24:1) and centrifuged 12,000 rpm 10 minutes. $400 \mu \mathrm{l}$ supernatant were taken carefully in to new labeled eppendorf tube $700 \mu \mathrm{l}$ chilled isopropanol was added to each tube and mixed gently. Tubes were incubated at $4{ }^{\circ} \mathrm{C}$ over night and centrifugation 12,000 rpm for 10 minutes. Supernatant was discarded and DNA pellet was rinsed with $70 \%$ ethanol. DNA pellet was air dried. The pellet was dissolved in $100 \mu \mathrm{l} \mathrm{TE}$ buffer (10 mM Tris, 1mM EDTA and PH: 8.0). RNAase-A was used to remove RNA from the DNA. For this purpose RNAase-A $(0.20 \mu$ l of RNAase-A procured from Gene Link, USA) $40 \mu \mathrm{g}$ was used and DNA samples were kept at $37^{\circ} \mathrm{C}$ for 30 minutes in water bath. DNA quantification was carried out in spectrophotometer. A 20 ng dilution of DNA was made in deionized water to use in Polymerase Chain Reaction (PCR). DNA samples were stored at $-20{ }^{\circ} \mathrm{C}$.

Table 1. Primers and their oligonucleotide sequences used

\begin{tabular}{|c|c|c|}
\hline Primer number & Primer Code & Sequence $3^{\prime}---5^{\prime}$ \\
\hline 1 & OPN-04 & 5 - GACCGACCCA -3 \\
\hline 2 & OPD-05 & $5 `-$ TGAGCGGACA -3` \\
\hline 3 & OPC-05 & $5^{`}-\mathrm{GATGACCGCC}-3^{`}$ \\
\hline 4 & OPB-07 & 5'-GAAACGGGTG -3` \\
\hline 5 & OPN-10 & 5-ACAACTGGGG -3` \\
\hline 6 & OPG-12 & $5^{`}$-CAGCTCACGA -3` \\
\hline 7 & OPQ-12 & 5`-AGTAGGGCAC -3` \\
\hline 8 & OPQ-14 & 5'-GGACGCTTCA -3 \\
\hline
\end{tabular}




\section{The polymerase chain reaction (PCR) conditions:}

RAPD analysis was carried out using eight oligonucleotide primers (Table 1) that were selected from the Operon Kit (Operon Technologies Inc., Alabameda, CA). The polymerase chain reaction mixture $(25 \mu \mathrm{l})$ consisted of $13 \mu \mathrm{l}$ master mix (Promega) Taq DNA polymerase; $2 \mu \mathrm{l}$ of genomic DNA, $2 \mu \mathrm{l}$ primer, $8 \mu 1$ deionized water. PCR amplification was performed in a Biometra T1 gradient thermal cycler for 35 cycles after initial denaturation for $5 \mathrm{~min}$ at $94^{\circ} \mathrm{C}$. Each cycle consisted of denaturation at $94^{\circ} \mathrm{C}$ for $1 \mathrm{~min}$; annealing at $36^{\circ} \mathrm{C}$ for $1 \mathrm{~min}$; extension at $72^{\circ} \mathrm{C}$ for $2 \mathrm{~min}$ and final extension at $72^{\circ} \mathrm{C}$ for $5 \mathrm{~min}$ (Williames, et al. 1990). Amplification products were separated on $2 \%$ Agarose gels at 100 volts for $1.30 \mathrm{hrs}$ with $1 \mathrm{x}$ TBE buffer. To detect ethidium bromide/DNA complex, Agarose gels were examined on ultra violet transilluminator (302nm wavelength) and photographed. Using 100pb Plus DNA ladder, ready-touse (Gene Ruler, Fermentas, and Life Sciences), the lengths of the different DNA fragments were determined. For each sample, the reproducible DNA bands from two runs were scored for their presence or absence.

Fragments scored as present/absent. Fragment scoring and lane matching performed automatically on digital images of the gels, using Phoretix 1D advanced Version 4.00 (Phoretix International, Newcastle upon Tyne, UK). All but the faintest bands scored, where necessary scores and matches corrected manually. Clustering methods and similarity coefficients were tested usingthe procedures SIMQUAL, SAHN, and TREE from the program NTSYSpcversion 2.10 (Applied Biostatistics, Setauket, New York, USA).The clustering methods UPGMA, WPGMA, Completelink, and Single-link were applied in all possible combinations withthe similarity coefficients Dice, Jaccard and simple matching. Phoretix electrophoresis gel image analysis, ID software was used for scanogram tracing of protein bands of the tissues. The molecular weights of protein bands were determined against protein calibration kits (Spectra $^{\mathrm{TM}}$ Multicolor Broa Range Protein Ladder; fermentas life sciencesunder the license for Strep-tag ${ }^{\circledR}$ technology). Data matrices were entered into the NTSYS (Numerical Taxonomic and Multivariate Analysis System) program, version 2.1, Applied Biostatistics Inc. (Rohlf, 2000). Similarity coefficients were used to construct dendrograms using the UPGMA (Unweighted Pair Group Method with Arithmetic average) and the SAHN (Sequential Agglomerative Hierarchical Nested clustering) routing in the NTSYS software. One Way ANOVA in completely randomized design was used to reveal the significant differences among the samples. The L.S.D. (least significant differences) test was conducted to identify the significant differences among the means at $5 \%$ level of probability. Comparison of the mean values is usually calculated after an ANOVA.

\section{RESULTS AND DISCUSSION}

\section{Morphological characteristics:}

Results in Table 2 indicated high significant variations among all studied stevia genotype in relation to plant height $(\mathrm{cm})$. The heighest plant height values were recorded to genotype- 7 by mean $123 \mathrm{~cm}$ followed by genotype 17 in average $(113.87 \mathrm{~cm})$ and genotype 5 in average $(112.25 \mathrm{~cm})$, while genotypes 13,15 and 10 were the shortest genotypes in average 48, 43.75 and $41.25 \mathrm{~cm}$, respectively. Analysis of variance in Table 2 showed high significant variation between all the stevia genotypes in relation to plant height by L.S.D. ${ }_{0.05}=$ 12.64, and also data indicated that no significant variations were observed among genotypes 2 and 3 . Huge number of secondary branches was observed to the genotype 3 by mean $4.5 \mathrm{branch} / \mathrm{plant}$, followed by genotypes 7, 11 and 13 showed an average 3.5 branch/plant and were no significant variation between them with L.S.D=2.04. On the other hand no significant variation was observed between the other genotypes in relation to current traits (Table 2).

Data in Table 2 showed that genotype 14 has the highest value in fresh weight of leaves $(\mathrm{g})$ by an average of $(9.66 \mathrm{~g})$ followed genotype $19(6.19 \mathrm{~g})$, genotype $9(5.98 \mathrm{~g})$ and genotype 16 by $5.95 \mathrm{~g}$ with $\mathrm{L}$. $\mathrm{S}$. $\mathrm{D}_{0.05}=2.86$. The results showed high significant variation between all genotypes of stevia in fresh weight of leaves $(\mathrm{g})$. The lowest value was recorded to genotype 2 by average $(2.45 \mathrm{~g})$ as showed in Table 3 and Figure 4. Data in Table 2 showed that genotype 19 has the highest value in dry weight of leaves $(\mathrm{g})$ by an average of $(2.34 \mathrm{~g})$ followed genotype $14(1.84 \mathrm{~g})$ and genotype $16(1.63 \mathrm{~g})$ with L.S. $D_{0.05}=1.57$. The results showed that all genotypes aren't significantly differed from each other except genotype 2 who recorded the lowest dry weight of leaves $(0.5 \mathrm{~g})$ as showed in Table 3 and Figure 5. Finally, data in Table 2 showed that genotype 18 has the highest value in mositure content/ leaves $(\%)$ by an average of $(84.83 \%)$ followed genotype $17(83.90 \%)$ and genotype $9(82.78 \%)$ by L.S. $D_{0.05}=2.23$. The results showed high significant variation between all genotypes of stevia in mositure content/ leaves (\%) and the lowest value was recorded to genotype 19 by average $(62.26 \%)$ as showed in Table 2. 
Table 2. Plant height(cm) and Number of branches/ plant, Fresh, Dry weight/leaves (gm) and Mositure content/leaves (\%) of nineteen genotypes of Stevia rebaudiana Bertoni from stem cuttings during 2014-2015 season

\begin{tabular}{|c|c|c|c|c|c|}
\hline Genotype & $\begin{array}{l}\text { Plant height } \\
\text { (cm) }\end{array}$ & $\begin{array}{c}\text { Number of } \\
\text { secondary } \\
\text { branches/ plant }\end{array}$ & $\begin{array}{c}\text { Fresh } \\
\text { weight/leaves/ } \\
\text { Plant (gm) }\end{array}$ & $\begin{array}{c}\text { Dry } \\
\text { weight /leaves/ } \\
\text { plant (gm) }\end{array}$ & $\begin{array}{l}\text { Moisture } \\
\text { content / } \\
\text { leaves }(\%)\end{array}$ \\
\hline Genotype 1 & $77.75^{\mathrm{fg}}$ & $2.0^{\mathrm{b}}$ & $3.17^{\mathrm{b}}$ & $0.59^{\mathrm{a}}$ & $81.08^{\mathrm{b}}$ \\
\hline Genotype 2 & $98.50^{\text {bcde }}$ & $2.5^{\mathrm{ab}}$ & $2.45^{b}$ & $0.51^{\mathrm{a}}$ & $78.76^{\mathrm{b}}$ \\
\hline Genotype 3 & $98.5^{\text {bcde }}$ & $4.5^{\mathrm{a}}$ & $5.00^{\mathrm{ab}}$ & $1.12^{\mathrm{a}}$ & $77.08^{\mathrm{ab}}$ \\
\hline Genotype 4 & $83.75^{\text {efg }}$ & $3.0^{\mathrm{ab}}$ & $3.83^{b}$ & $0.88^{\mathrm{a}}$ & $76.98^{b}$ \\
\hline Genotype_5 & $112.25^{\mathrm{ab}}$ & $2.0^{\mathrm{b}}$ & $5.23^{\mathrm{ab}}$ & $1.25^{\mathrm{a}}$ & $76.25^{\mathrm{ab}}$ \\
\hline Genotype_6 & $108.25^{\mathrm{abc}}$ & $2.5^{\mathrm{ab}}$ & $4.98^{\mathrm{a}}$ & $1.35^{\mathrm{a}}$ & $74.41^{\mathrm{a}}$ \\
\hline Genotype 7 & $123.00^{\mathrm{a}}$ & $3.5^{\mathrm{ab}}$ & $4.00^{b}$ & $0.76^{\mathrm{a}}$ & $80.68^{b}$ \\
\hline Genotype 8 & $84.50^{\text {efg }}$ & $2.0^{\mathrm{ab}}$ & $3.80^{\mathrm{b}}$ & $0.91^{\mathrm{a}}$ & $76.60^{b}$ \\
\hline Genotype 9 & $80.00^{\text {efg }}$ & $2.0^{\mathrm{b}}$ & $5.98^{\mathrm{ab}}$ & $0.80^{\mathrm{a}}$ & $82.78^{\mathrm{ab}}$ \\
\hline Genotype_10 & $41.25^{\mathrm{h}}$ & $2.6^{\mathrm{ab}}$ & $3.15^{b}$ & $0.62^{\mathrm{a}}$ & $79.09^{b}$ \\
\hline Genotype 11 & $68.50^{\mathrm{g}}$ & $3.5^{\mathrm{ab}}$ & $3.76^{b}$ & $0.79^{\mathrm{a}}$ & $77.85^{b}$ \\
\hline Genotype 12 & $67.50^{\mathrm{g}}$ & $2.5^{\mathrm{ab}}$ & $4.99^{\mathrm{ab}}$ & $1.14^{\mathrm{a}}$ & $77.27^{\mathrm{ab}}$ \\
\hline Genotype 13 & $48.00^{\mathrm{h}}$ & 3.5 & $4.33^{b}$ & $0.95^{\mathrm{a}}$ & $77.80^{\mathrm{b}}$ \\
\hline Genotype 14 & $91.75^{\mathrm{cdef}}$ & $2.0^{\mathrm{b}}$ & $9.66^{\mathrm{a}}$ & $1.84^{\mathrm{a}}$ & $81.26^{\mathrm{a}}$ \\
\hline Genotype_15 & $43.75^{\mathrm{h}}$ & $3.0^{\mathrm{ab}}$ & $5.15^{\mathrm{ab}}$ & $1.21^{\mathrm{a}}$ & $75.64^{\mathrm{ab}}$ \\
\hline Genotype 16 & $66.00^{\mathrm{g}}$ & $2.0^{\mathrm{b}}$ & $5.95^{\mathrm{ab}}$ & $1.63^{\mathrm{a}}$ & $72.68^{\mathrm{ab}}$ \\
\hline Genotype 17 & $113.87^{\mathrm{ab}}$ & $2.5^{\mathrm{ab}}$ & $3.35^{b}$ & $0.55^{\mathrm{a}}$ & $83.90^{\mathrm{b}}$ \\
\hline Genotype 18 & $50.00^{\mathrm{h}}$ & $0.0^{\mathrm{b}}$ & $5.79^{\mathrm{ab}}$ & $0.86^{\mathrm{a}}$ & $84.83^{\mathrm{ab}}$ \\
\hline Genotype 19 & $96.63^{\text {bcdef }}$ & $0.0^{\mathrm{b}}$ & $6.19^{\mathrm{a}}$ & $2.34^{\mathrm{a}}$ & $62.26^{\mathrm{a}}$ \\
\hline $\mathrm{LSD}={ }_{0.05}$ & 12.64 & 2.04 & 2.86 & 1.57 & 2.23 \\
\hline
\end{tabular}

Data in Table 3 showed that genotype 19 has the highest value in fresh weight of stems $(\mathrm{g})$ by average $9.47 \mathrm{~g}$ followed genotype $16(8.42 \mathrm{~g})$ and genotype 4 $(7.97 \mathrm{~g})$ with L.S. $\mathrm{D}_{0.05}=5.43$. The results showed that all genotypes were not significantly differed from each other except genotype 10 who recorded the lowest fresh weight of stems was genotype 10 by an average of (3.18 g) as showed in Table 3. Data in Table 3 showed that genotype 19 has the highest value in dry weight of stems $(\mathrm{g})$ by average of (2.15) followed genotype 6 $(1.74 \mathrm{~g})$ and genotype $1(1.6 \mathrm{~g})$ with L.S. $\mathrm{D}_{0.05}=1.26$. The results showed significant variations between all genotypes of stevia in dry weight of stems and detected the lowest value for genotype 10 by average $(0.5 \mathrm{~g})$ as shown in Table 4 and Figure 7. Results in Table 3 showed that genotype 3 has the highest value in mositure content/ stems (\%) by average of $(84.43 \%)$ followed genotype $11(83.02 \%)$ and genotype 18 $(82.85 \%)$ by L.S.D. $D_{0.05}=4.29$. The results showed significant variation between all genotypes of stevia in moisture content of stems. The lowest value was recorded to genotype 1 by average ( $74 \%$ ) as showed in Table 3.

The previous data showed that high significant variations between all the genotypes in relation to the morphological characteristics had achieved. That means there is high genetic diversity between these genotypes due to the open pollination for these genotypes several years and theses genotypes could sed in the future breeding programme.

These results are in agreement that accepted by Abdullateef and Osman (2011) who's evaluated 10 stevia accessions in Malaysia using morphological parameters and collected data were subjected to ' $t$ ' test analysis. Also, our results are agreed with Kassahun et al., (2013) worked on some morphological character on Stevia rebaudiana Bertoni. Data on survival count, survival percentage, number of branches/seedlings, number of leaves/branches and number of leaves/seedlings were recorded. The results showed that Mean squares from analysis of variance revealed the existence of a very highly significant influence $(P<$ 0.001 ) of cutting position, node number and interaction effect of cutting position withnode numbers on all the parameters considered in the study. The current work is agreed with Shizhen, and Wanzhong (1988) studied the variation of 14 important quantity character of Stevia rebaudiana $\mathrm{B}$. and the influence of different density on the variation. 
Table 3. Fresh weight /stems (g) and Number of branches/ plant of nineteen genotypes of Stevia rebaudiana Bertoni from stem cuttings during season 2014-2015

\begin{tabular}{lccc}
\hline Genotype & $\begin{array}{c}\text { Fresh weight /stems } \\
\text { /plant (gm) }\end{array}$ & $\begin{array}{c}\text { Dry weight/stems } \\
\text { /plant (gm) }\end{array}$ & $\begin{array}{c}\text { Moisture content /stems } \\
\text { (\%) }\end{array}$ \\
\hline Genotype_1 & $6.2^{\mathrm{b}}$ & $1.68^{\mathrm{b}}$ & $74.00^{\mathrm{b}}$ \\
\hline Genotype_2 & $7.78^{\mathrm{b}}$ & $0.89^{\mathrm{b}}$ & $79.65^{\mathrm{b}}$ \\
\hline Genotype_3 & $6.5^{\mathrm{b}}$ & $1.3^{\mathrm{b}}$ & $84.43^{\mathrm{b}}$ \\
\hline Genotype_4 & $7.97^{\mathrm{b}}$ & $1.6^{\mathrm{b}}$ & $79.92^{\mathrm{b}}$ \\
\hline Genotype_5 & $4.40^{\mathrm{b}}$ & $0.87^{\mathrm{b}}$ & $80.42^{\mathrm{b}}$ \\
\hline Genotype_6 & $6.12^{\mathrm{a}}$ & $1.74^{\mathrm{a}}$ & $81.67^{\mathrm{a}}$ \\
\hline Genotype_7 & $5.70^{\mathrm{b}}$ & $1.38^{\mathrm{b}}$ & $76.01^{\mathrm{b}}$ \\
\hline Genotype_8 & $4.57^{\mathrm{b}}$ & $0.97^{\mathrm{b}}$ & $78.93^{\mathrm{b}}$ \\
\hline Genotype_9 & $4.80^{\mathrm{b}}$ & $0.97^{\mathrm{b}}$ & $79.59^{\mathrm{b}}$ \\
\hline Genotype_10 & $3.18^{\mathrm{b}}$ & $0.57^{\mathrm{b}}$ & $81.98^{\mathrm{b}}$ \\
\hline Genotype_11 & $6.90^{\mathrm{b}}$ & $1.16^{\mathrm{b}}$ & $83.02^{\mathrm{b}}$ \\
\hline Genotype_12 & $6.65^{\mathrm{b}}$ & $1.25^{\mathrm{b}}$ & $78.96^{\mathrm{b}}$ \\
\hline Genotype_13 & $4.01^{\mathrm{b}}$ & $0.88^{\mathrm{b}}$ & $79.08^{\mathrm{b}}$ \\
\hline Genotype_14 & $4.52^{\mathrm{b}}$ & $0.91^{\mathrm{b}}$ & $79.73^{\mathrm{b}}$ \\
\hline Genotype_15 & $5.68^{\mathrm{b}}$ & $1.36^{\mathrm{b}}$ & $75.60^{\mathrm{b}}$ \\
\hline Genotype_16 & $8.42^{\mathrm{b}}$ & $1.64^{\mathrm{b}}$ & $80.71^{\mathrm{b}}$ \\
\hline Genotype_17 & $1.01^{\mathrm{b}}$ & $79.37^{\mathrm{b}}$ \\
\hline Genotype_18 & $4.92^{\mathrm{b}}$ & $1.26^{\mathrm{b}}$ & $82.85^{\mathrm{b}}$ \\
\hline Genotype_19 & $7.32^{\mathrm{b}}$ & $2.15^{\mathrm{b}}$ & $77.50^{\mathrm{b}}$ \\
\hline LSD= 0.05 & $9.47^{\mathrm{b}}$ & 1.26 & 4.29 \\
\hline The & 5.43 & $T h$ & \\
\hline
\end{tabular}

The results indicate the variation tended to appear similar in the same character. Some of the characters were more stable, namely the paired leaf numbers, number of nods before transplanting, transplanting and plant height, number of nods, length of leaf at harvest time. Some of the character was not stable, namely the number of branch and the yield of dry, fresh culm, leaf. The result of the analysis for character correlation was shown that some characters, closely related to yield, first of all were dry leaf weight, fresh leaf weight, fresh culm weight, dry culm weight per plant, then, culm width, number of branch, and the third, plant height, number of nod, paired leaf number before transplanting. The results agree with Oliveira et al., (2004) who examined some morphological features of strains of Stevia rebaudiana. The current research was in the line with Brandle and Rosa (1992) who studied the genetic variability in locallya vailable stevia germplasm to allow selection of lines with agronomic and chemical properties suitable to local production conditions. They found that yield, leaf: stem ratio and stevioside concentration (62.1, 78.8 and 76.6, respectively) they were highly heritable. Yield levels were comparable to other stevia producing areas. Stevioside concentration was higher, probably as a result of production under long days. These initial results also showed that clearly suggested that genetic improvement of stevia is possible. These high heritabilities enable selection and breeding programs, aimed at higher yield, to achieve substantial gains.

\section{Extraction and estimation of Stevia sweeteners}

Stevia sweeteners were analyzed and determined employing the high performance liquid chromatography HPLC. Data in Table 4 and Figures 1-2 showed the analysis of Stevia sweeteners (Stevioside (\%) and rebaudioside-A). The results clearly indicated there were high significant variations between the nineteen genotypes under the study. The results showed that the hieghest concentration of rebaudioside-A was (28.2\%) in genotype (6), and decreased to be $(0.08 \%$ and $0.09 \%)$ in genotypes (12 and 13), respectively, as the lowest two genotypes in contrast in stevioside percentage the results showed that the highest percentage of stevioside was $(99.5 \%)$ in genotype (12) followed by genotype (10) by $(99.2 \%)$, and decreased to be $(42.3 \%$ and $34.4 \%$ in genotypes ( 6 and 11$)$ respectively. From the previous data, we can conculaded that the different in rebaudioside $\mathrm{A}$ due to the different in the genetic background because these 19 geneotypes were grew and polanated rondamly for many different seasones. The data detected negatively correlation between stevioside and rebaudioside-A. 

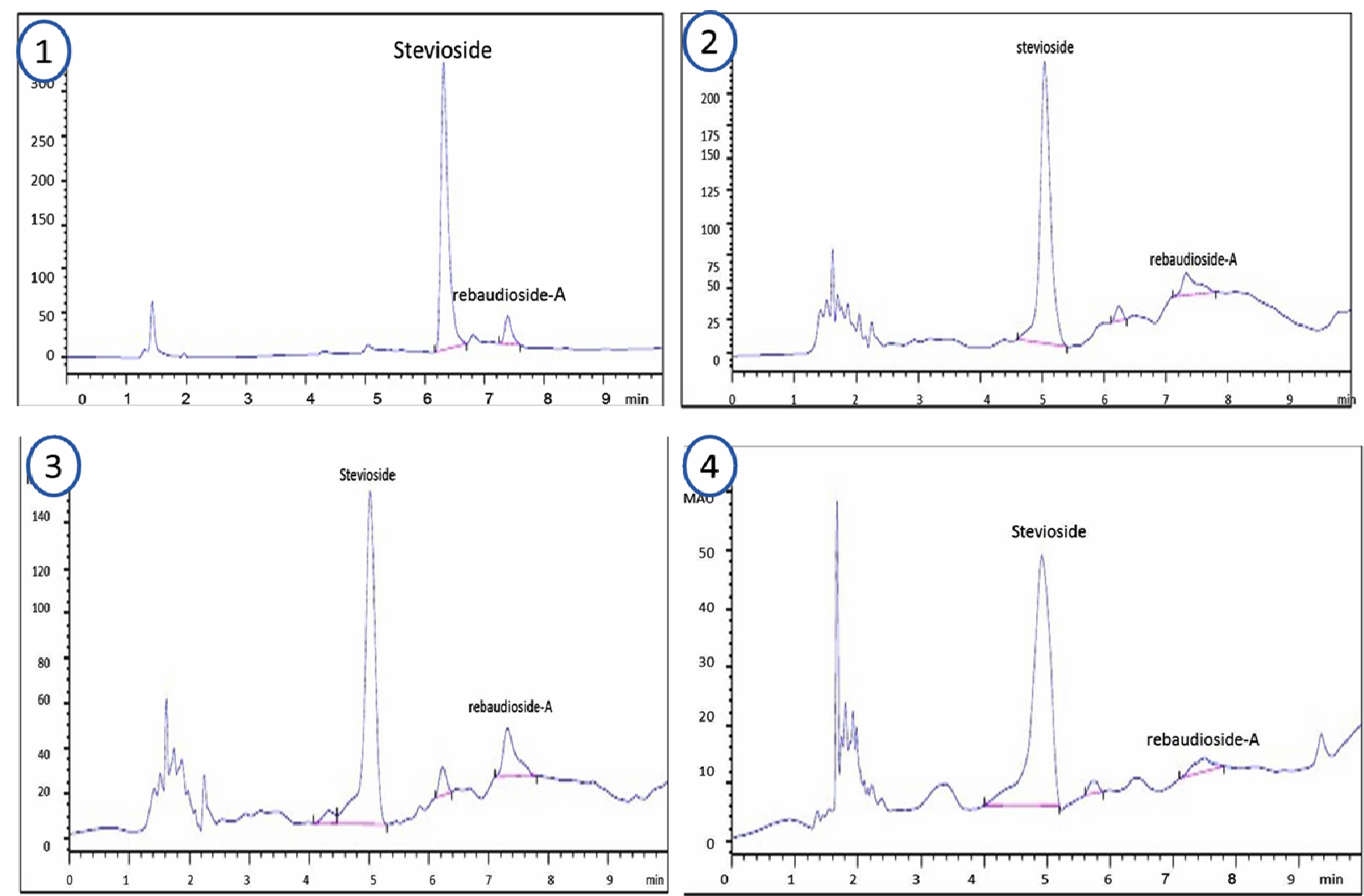

Figure 1. HPLC Chromatogram of stevioside and rebaudioside-A in relation to total sweeteners: (1) standard solution, (2) genotype_3, (3) genotype_4, and (4) genotype_5

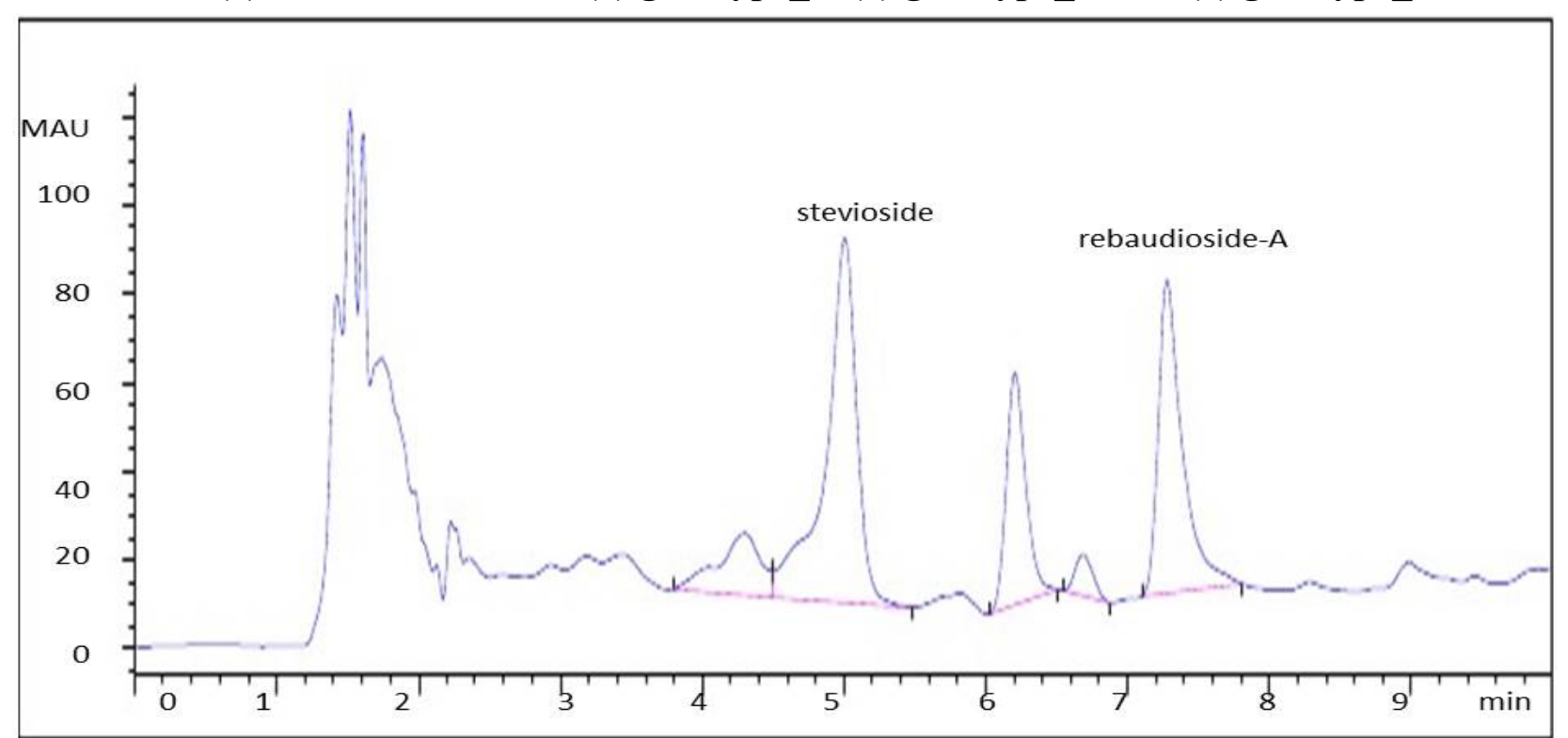

Figure 2. HPLC Chromatogram of stevioside and rebaudioside for genotype_6 in relation to total sweeteners 
Table 4. Analysis of stevioside and Rebaudioside-A from Stevia rebaudiana fresh leaves using HPLC in relation to total sweeteners

\begin{tabular}{lcc}
\hline Genotype; & Stevioside (\%) & Rebaudioside-A (\%) \\
\hline Genotype_1 & 93.7 & 1.08 \\
Genotype_2 & 91.8 & 4.30 \\
Genotype_3 & 87.4 & 9.57 \\
Genotype_4 & 78.5 & 13.7 \\
Genotype_5 & 92.4 & 5.19 \\
Genotype_6 & 42.3 & 28.2 \\
Genotype_7 & 92.2 & - \\
Genotype_8 & 93.8 & - \\
Genotype_9 & 98.2 & - \\
Genotype_10 & 99.2 & - \\
Genotype_11 & 34.4 & 0.32 \\
Genotype_12 & 99.5 & 0.08 \\
Genotype_13 & 97.4 & 0.09 \\
Genotype_14 & 81.8 & 0.11 \\
Genotype_15 & 98.4 & 0.15 \\
Genotype_16 & 97.5 & 0.13 \\
Genotype_17 & 98.1 & 0.53 \\
Genotype_18 & 83.2 & - \\
Genotype_19 & 87.7 & 0.57 \\
\hline
\end{tabular}

These correlations can be partially explained by the biosynthetic relationships between the individual glycosides because stevioside is the substrate for the synthesis of rebaudioside A. the plants which have high concenteration in rebaudioside A will probably be low in stevioside.

These results are in agreenent with Shibata et al., (1995) who observed a wide range of variation in the four main glycosides and found that dulcoside $\mathrm{A}$ and stevioside, and rebaudioside $\mathrm{A}$ and $\mathrm{C}$, and it were positively correlated with each other. Stevioside and rebaudioside $\mathrm{A}$, and dulcoside and rebaudioside $\mathrm{C}$, were negatively correlated with each other. These correlations can be partially explained by the biosynthetic relationships between the individual glycosides because stevioside is the substrate for the synthesis of rebaudioside A, plants high in rebaudioside A will probably be low in stevioside. The current results is agree with Huang et al., (1995) who investigated the seedling population and clone variation from the difference of sweet component andcontent in Stevia rebaudiana Bertoni. The results showed: (1) there are $7.3 \%$ high yielding plants in seedling population, in which the proportion of R-A type with content of R-A over St content is $10.96 \%$, and their R-A content varies from 3.3 to $12.0 \%$. (2) Among the selected improved clone $\mathrm{J}-2$, there are high significant difference in leaf size and steviosides content. The R-A content varies from 4.5 to $12.2 \%$. (3) The individuals with R-A content of 7.04 apprx $12.03 \%$ from seedling population (original content $3.86 \%$ ) and individuals with R-A content of 10.15 apprx $12.15 \%$ from improved individual clone (original content 9.10\%) were selected out.

\section{RAPD-PCR ANALYSIS}

Plant molecular geneticists are currently used RAPD markers routinely to identify genetic variations (Keil and Griffin, 1994; Lashermes et al. 1996; Irwin et al., 1998 and Sun et al. 1998). RAPD markers have been also used successfully in various taxonomic and Phylogenetic studies. In addition, it locates regions of the genome linked to agronomically important genes (Reiter et al., 1992; Martin et al., 1991; Michelmore et al., 1991; Pillay and Kenny 1996). Furthermore, it facilitates introgression of desirable genes into commercial accessions (Lavi et al., 1994). In the present study, the genetic variability and relationships of different genotypes of Stevia (Stevia rebaudiana) have been studied based on RAPD analysis. Initial screening of large number of RAPD primers with ninteen genotypes of stevia (Stevia rebaudiana) resulted in eight RAPD primers that produced in formative and polymorphic products resolvable by agarose gel electrophoresis.

The results of primer OPN-04 are illustrated in Table 5. The total fragments were 61 amplification products at the fragment lengths ranged between 237 to $3000 \mathrm{bp}$. One of 61 fragments was monomorphic (300 bp) and 15 fragments were polymorphic i.e. (3000, 2841, 1825, 1707, 1413, 937, 895, 877, 822, 794, 790, 
$700,529,500$ and 469 bp)and 45 fragments were unique $(2684,2377,2230,2088,1598,1500,1338$, 1273, 1220, 1128, 1073, 1065, 1040, 1019, 1000, 986, $982,966,950,923,900,898,886,845,842,831,810$, $807,790,767,737,734,718,674,656,634,632,615$, 581, 472, 438, 394, 378, 268 and 237 bp). The percentage of the polymorphism was $98.36 \%$. Results showed that the genotypes number $2,6,7,11,12,14$, 15,16 and 9 gave the same number of fragments $(5,6)$ respectively, While the genotypes $1,8,10,17$ and 18 detected the highest number of fragments ( 7 fragments). In the same time genotypes 5, 13 and 19 recorded the lowest number of fragments (4 fragments). On the other hand, the genotypes 3 doesn't amplified any fragments and he missing during loading procedure (Table 5)

The total fragments were 63 amplification products at the fragment lengths ranged between 127 to $2710 \mathrm{bp}$ for OPD-05 primer. One monomorphic fragment was detected (1000 bp), 21 fragments were polymorphic and 41 fragments were unique. The percentage of the polymorphism was $98.4 \%$. Results in Table 6 showed that genotypes 13 recorded (2 fragments, 3 (five fragments), while all the fowling genotypes $(1,18),(16$, $17),(9,15),(4,10,11)$ and $(2,6,7,8)$ detected the same number of fragments $(1,18),(16,17),(9,15),(4$, $10,11)$ and $(2,6,7,8)$, respectively. On the other hand genotype 3 detected 5 fragments. The highest numbers of DNA fragments were recorded to genotypes 14, 19 by 9 fragments. While, genotype 13 amplified the lowest DNA fragments number (2 fragments) and finally genotype 12 doesn 't amplified any fragment.

The results of OPC-05 primer are illustrated in Table 7. The total fragments were 73 amplification products at the fragment lengths ranged between 100 to 2528 bp. Four fragments were monomorphic (1000, $700,500$ and $300 \mathrm{bp})$ and 18 fragments were polymorphic. The percentage of the polymorphism was $94.5 \%$. Results in Table 7 showed that the highest number of DNA fragments was 13 fragments recorded to the genotypes 18 . Genotypes 17 and 19 recorded 11 and 12 fragments, in respect. Genotypes $(5,8,9),(2,4$, $15),(6,7,10,13)$ and $(14,11,16)$ detected the same number of fragments $(7,8,9$ and 10), respectively. On the other hand, the genotype 3, 12 amplified the lowest DNA fragments number (6 fragments). The total fragments by using primer OPB-07 were 28 amplification products at the fragment lengths ranged between 300 to 2429 bp. Two of 28 fragments were monomorphic (1435 and $801 \mathrm{bp}$ ) and seven fragments were polymorphic. 19 of 28 fragments were unique and the percentage of the polymorphism was $92.85 \%$. (Table 8).
Results showed that genotypes 2, 6, 12, 15 and 4, 8, $9,13,16$ detected the same number of fragments ( 3 and 4 fragments, respectively), while the genotypes $3,7,10$, 11,18 and 19 showed the highest number of DNA fragments (5 fragments). On the other hand, the genotype 14 amplified the lowest DNA fragments number (2 fragments). Genotypes 5, 17 don't gave any fragments.

The results of primer OPN-10 are illustrated in Table 9. The total fragments were 22 amplification products at the fragment lengths ranged between 628 to $2738 \mathrm{bp}$. One fragment of 22 was monomorphic (1015 bp), six of 22 fragments were polymorphic $(2738,995$, $898,890,883$ and $628 \mathrm{bp}$ ) and 15 fragments were Unique $(2483,1781,1679,1585,983,939,909,900$, $876,830,787,756,688,680$ and $648 \mathrm{bp})$. The percentage of the polymorphism was $95.45 \%$. Results showed that genotypes $(2,5,7,9,11,14,17,19)$ and genotypes $(3,4,6,10,18)$ detected the same number of fragments ( 2 and 3 fragments), respectively, while, the genotypes 1,15 and 16 showed the highest number of DNA fragments (4 fragments). On the other hand, the genotypes 8, 12 and 13 don`t gave any fragments.

Concerning to primer OPN-10 found in Table 10, the total fragments were 17 amplification products at the fragment lengths ranged between 113 to $1405 \mathrm{bp}$. one of 17 fragments was monomorphic (500 bp), one of 17 fragments was polymorphic $(665 \mathrm{bp})$ and 15 fragments were unique. The percentage of the polymorphism was $94 \%$. With primer OPQ-12 the total fragments were 19 amplification products at the fragment lengths ranged between $176 \mathrm{bp}$. to $1018 \mathrm{bp}$. one of 19 fragments was monomorphic (714 bp), 4 of 19 fragments was polymorphic $(775,742,728$, and 176 bp) and 14 fragments were unique. The percentage of the polymorphism was $94.7 \%$ (Table 11). The results of primer OPQ-14 are illustrated in Table 12. The total fragments were 9 amplification products at the fragment lengths ranged between $190 \mathrm{bp}$. to $2316 \mathrm{bp}$. One of 9 fragments was monomorphic (190 bp), 2 of 9 fragments were polymorphic (612 and 829 bp) and 6 fragments were unique (2316, 1406, 926, 641, 222 and $197 \mathrm{bp}$ ). The percentage of the polymorphism was $89 \%$.

Data in Table 13 showed the primer name, total number of amplicons, monomorphic and polymorphic amplicons and the percentage of polymorphism among the nineteen genotypes. The mean precxentage of polymorphic was $94.65 \%$. 


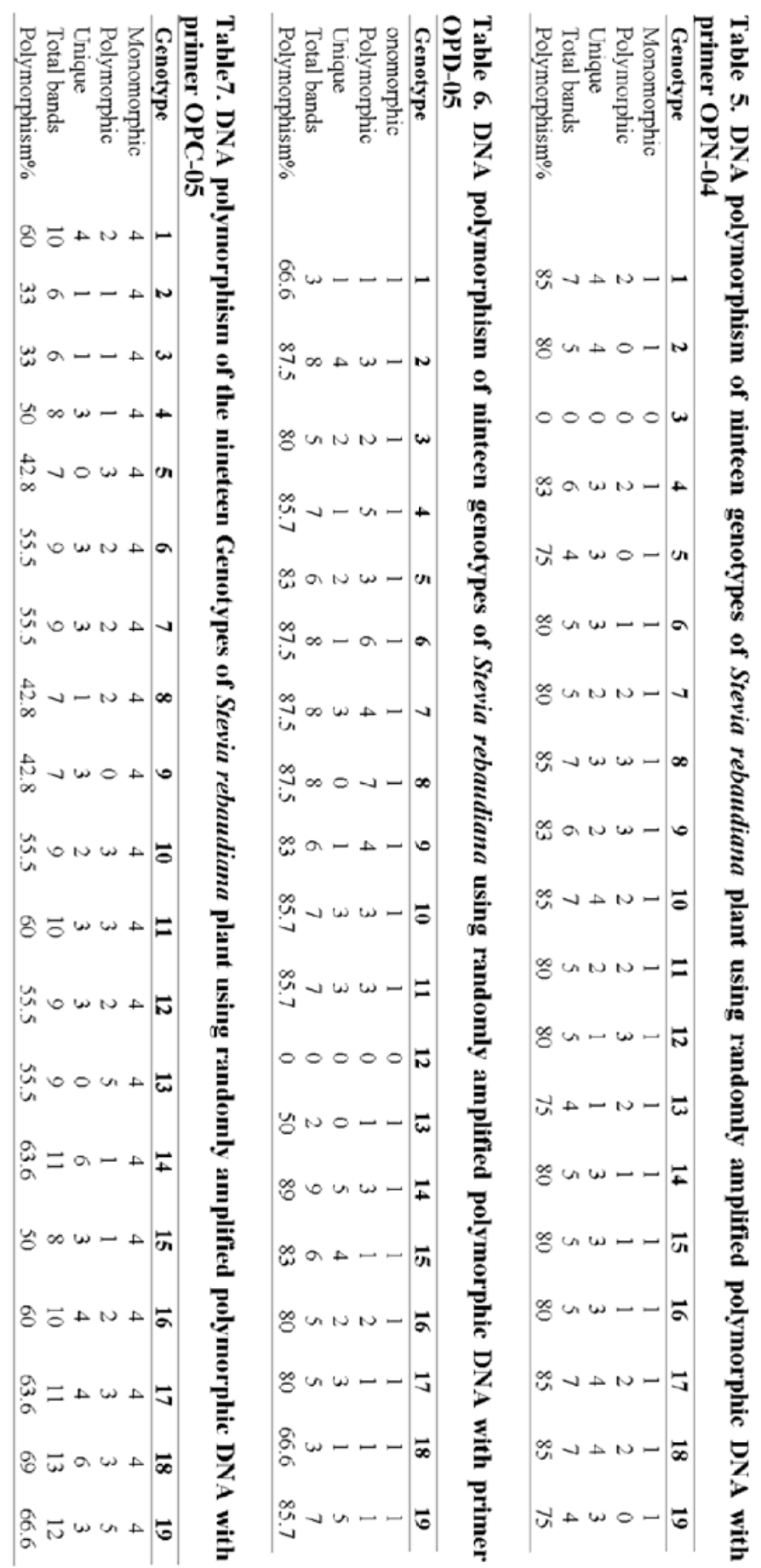




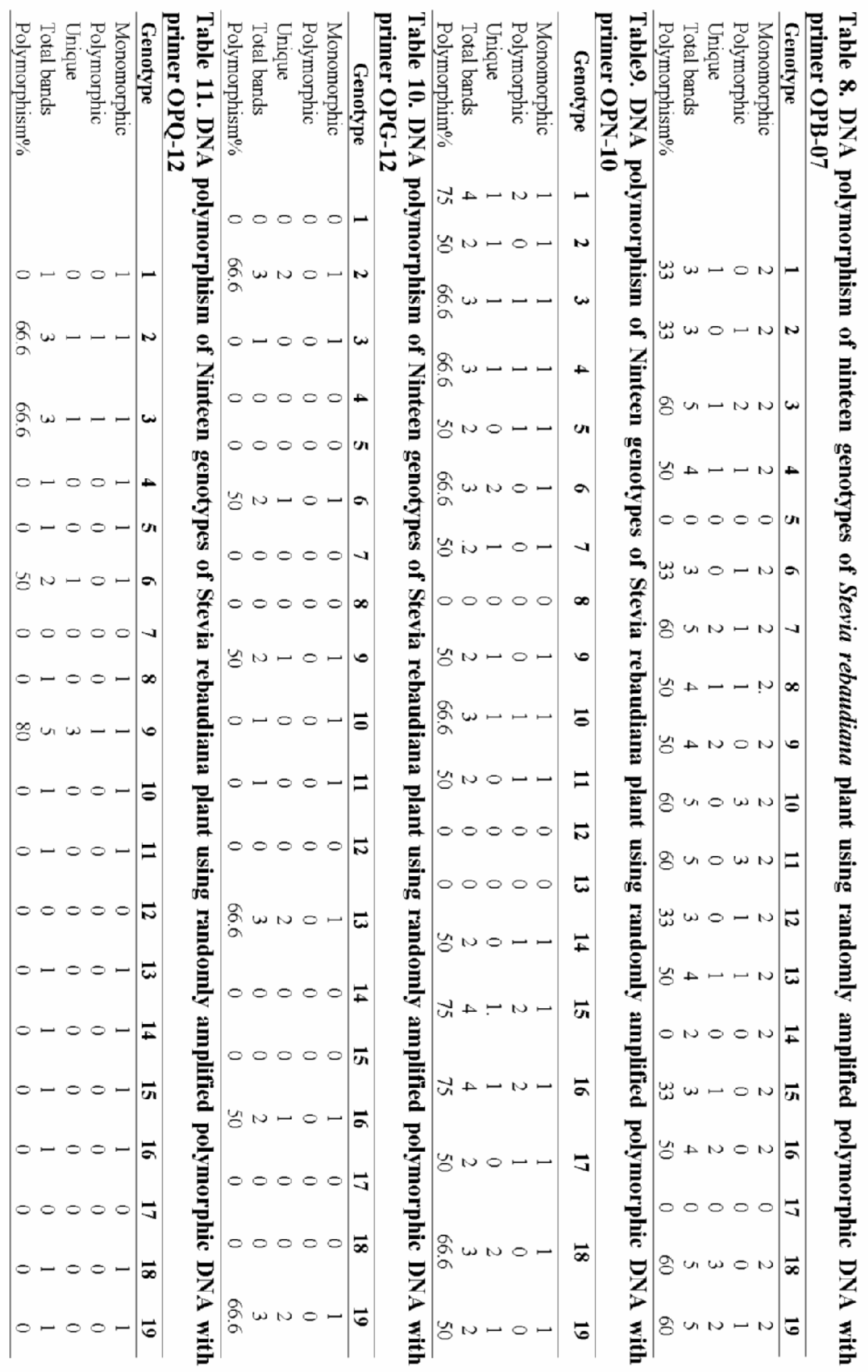


The genetic polymorphism between the nineteen genotypes ranged from $89 \%$ by using OPQ-14 to $98.4 \%$ with OPN-04 and OPD-05, in respect (Table 13). That mean there are high genetic diversity between the current genotypes and it could be used in the breeding program to obtaining new genetic resources from Stevia rebaudiana plants.

To study the genetic similarities and phylogenetic relationships among the ninteen tested genotypes of Stevia rebaudiana RAPD-PCR analysis were used. The obtained data were subjected to cluster analysis with dice equation by using NTYSIS (ver 2.1) computer program to calculate proximity matrix and design dendogram. In the present study the genetic relationships among the nineteen genotypes were determined by Dice coefficient. The matrix of similarity index ranged from 0.78 recorded between genotype 13 and 14 to 0.91 recorded between genotype 7 and 8 with an average of 0.80 . The dendrogram illustrating the distance among the examined genotype is presented in Figure 3. The dendogram in this case revealed two main groups (A \& B) by •, $\wedge$ \% similarity. The first group A consists of two clusters (genotype 9 and 3 ) by $84 \%$ similarity. Cluster B divided to two sub clusters ( $\mathrm{A}^{\prime}$ and $\left.\mathrm{B}^{\prime}\right)$ by $82.5 \%$ similarity. Sub cluster $\left(\mathrm{A}^{\prime}\right)$ divided to two three clusters and includes (Genotypes 19, 18, 16, 13) by $83 \%$ similarity. Sub cluster $\left(\mathrm{B}^{\prime}\right)$ divided to two sub cluster $\left(A^{\prime \prime} \& B^{\prime /}\right)$. Sub cluster $A^{\prime \prime}$ includes two sub clusters AND genotypes 6, 7, 8, 10, 11, 14 and 15, while, sub cluster $\mathrm{B}^{/ /}$include both genotypes $1,2,4,5$, 12 and 17.

The current study was in the line with Moktaduzzaman and Rahman (2009) who worked on 9 randomly selected regenerated plants and subjected to RAPD analysis. Their results indicated that the estimation of genetic similarity coefficient based on RAPD band-sharing data indicated that some regenerated plants were $100 \%$ similar to the mother the mother plants and some were 71.57 or $14 \%$ similar may be due to in vitro condition. Also, our results are agree with Radhika et al., (2012) who worked on molecular genetic fingerprints of medicinal species using
Randomly Amplified Polymorphic DNA (RAPD) marker to elucidate the genetic diversity among the 18 species of stevia rebaudiana plant. The results indicated that of which 232 fragments were polymorphic with $96.84 \%$ of polymorphism. Some of the RAPD markers were useful for species discrimination and identification. Most of the RAPD markers studied showed different level of genetic polymorphism. Amplified fragment sizes ranged from 300 to $5000 \mathrm{bp}$. PairwiseNei and Li's similarity coefficient value ranged from $0.00-0.72$ for 18 species of medicinal plants. The results in the line with Chester et al., (2013) who studied the genetic and metabolic variability in $S$. rebaudiana among accessions of different geographical regions of India using random amplified polymorphic DNA (RAPD) markers. They found ten out of 20 primers screened were most informative; amplification products of the genotypes yielded a total of 87 scorable bands (67 polymorphic), whereas genetic similarity (GS) coefficient (0.01-0.08) and polymorphism (67.24$92.40 \%$ ) showed huge variability. The current results in the line with Paramanik and Chikkaswamy (2014) who assayed the genetic relationships between eighteen medicinal plants with RAPD markers. They showed that over 77.23 reproducible bands were generated by RAPD primers, out of which, 77.23 polymorphic bands were identified, conferring $97.6 \%$ polymorphism. All the primers produced typical banding in each of the medicinal plants, suggesting the applicability of this test in medicinal plant identification. Results of the current work is agreed with Chikkaswamy (2015) who investigated molecular genetic fingerprints of medicinal species using RAPD marker to elucidate the genetic diversity among the 18 species. Three decamer-primers generated 250 RAPD fragments, of which 232 fragments were polymorphic with $96.84 \%$ of polymorphism. Some of the RAPD markers were useful for species discrimination and identification. They maintained that most of the RAPD markers studied showed different level of genetic polymorphism. Amplified fragment sizes ranged from 300 to $5000 \mathrm{bp}$.

Table 12. DNA polymorphism of Ninteen genotypes of Stevia rebaudiana plant using randomly amplified polymorphic DNA with primer OPQ-14

\begin{tabular}{lccccccccccccccccccc}
\hline Genotype & $\mathbf{1}$ & $\mathbf{2}$ & $\mathbf{3}$ & $\mathbf{4}$ & $\mathbf{5}$ & $\mathbf{6}$ & $\mathbf{7}$ & $\mathbf{8}$ & $\mathbf{9}$ & $\mathbf{1 0}$ & $\mathbf{1 1}$ & $\mathbf{1 2}$ & $\mathbf{1 3}$ & $\mathbf{1 4}$ & $\mathbf{1 5}$ & $\mathbf{1 6}$ & $\mathbf{1 7}$ & $\mathbf{1 8}$ & $\mathbf{1 9}$ \\
\hline Monomorphic & 1 & 0 & 1 & 0 & 0 & 1 & 1 & 1 & 1 & 1 & 1 & 0 & 0 & 1 & 0 & 1 & 0 & 1 & 0 \\
Polymorphic & 0 & 0 & 0 & 0 & 0 & 0 & 0 & 0 & 0 & 2 & 2 & 0 & 0 & 0 & 0 & 0 & 0 & 0 & .0 \\
Unique & 2 & 0 & 0 & 0 & 0 & 1 & 1 & 0 & 0 & 0 & 1 & 0 & 0 & 1 & 0 & 0 & 0 & 0 & 0 \\
Total bands & 3 & 0 & 1 & 0 & 0 & 2 & 2 & 1 & 1 & 3 & 4 & 0 & 0 & 2 & 0 & 1 & 0 & 1 & 0 \\
Polymorphism\% & 66.6 & 0 & 0 & 0 & 0 & 50 & 50 & 0 & 0 & 66.6 & 75 & 0 & 0 & 50 & 0 & 0 & 0 & 0 & 0 \\
\hline
\end{tabular}


Table 13. Polymorphism data as detected by RAPD markers, total number of amplicons, monomorphic and polymorphic amplicons and the percentage of polymorphism among the nineteen genotypes

\begin{tabular}{cccccc}
\hline polymorphism $\%$ & unique & polymorphic & $\begin{array}{c}\text { Monomorphi } \\
\text { c }\end{array}$ & Total amplicons & Primer code \\
\hline 98.4 & 45 & 15 & 1 & 61 & OPN-04 \\
\hline 98.4 & 41 & 21 & 1 & 63 & OPD-05 \\
\hline 94.5 & 51 & 18 & 4 & 73 & OPC-05 \\
\hline 92.8 & 19 & 7 & 2 & 28 & OPB-07 \\
\hline 95.5 & 15 & 6 & 1 & 17 & OPN-10 \\
\hline 94.0 & 15 & 1 & 1 & 19 & OPG-12 \\
\hline 94.7 & 14 & 4 & 1 & 9 & OPQ-12 \\
\hline 89.0 & 6 & 2 & 1 & 292 & Total \\
\hline & 206 & 74 & 12 & Polymorphism \% \\
\hline 94.65 & & & &
\end{tabular}

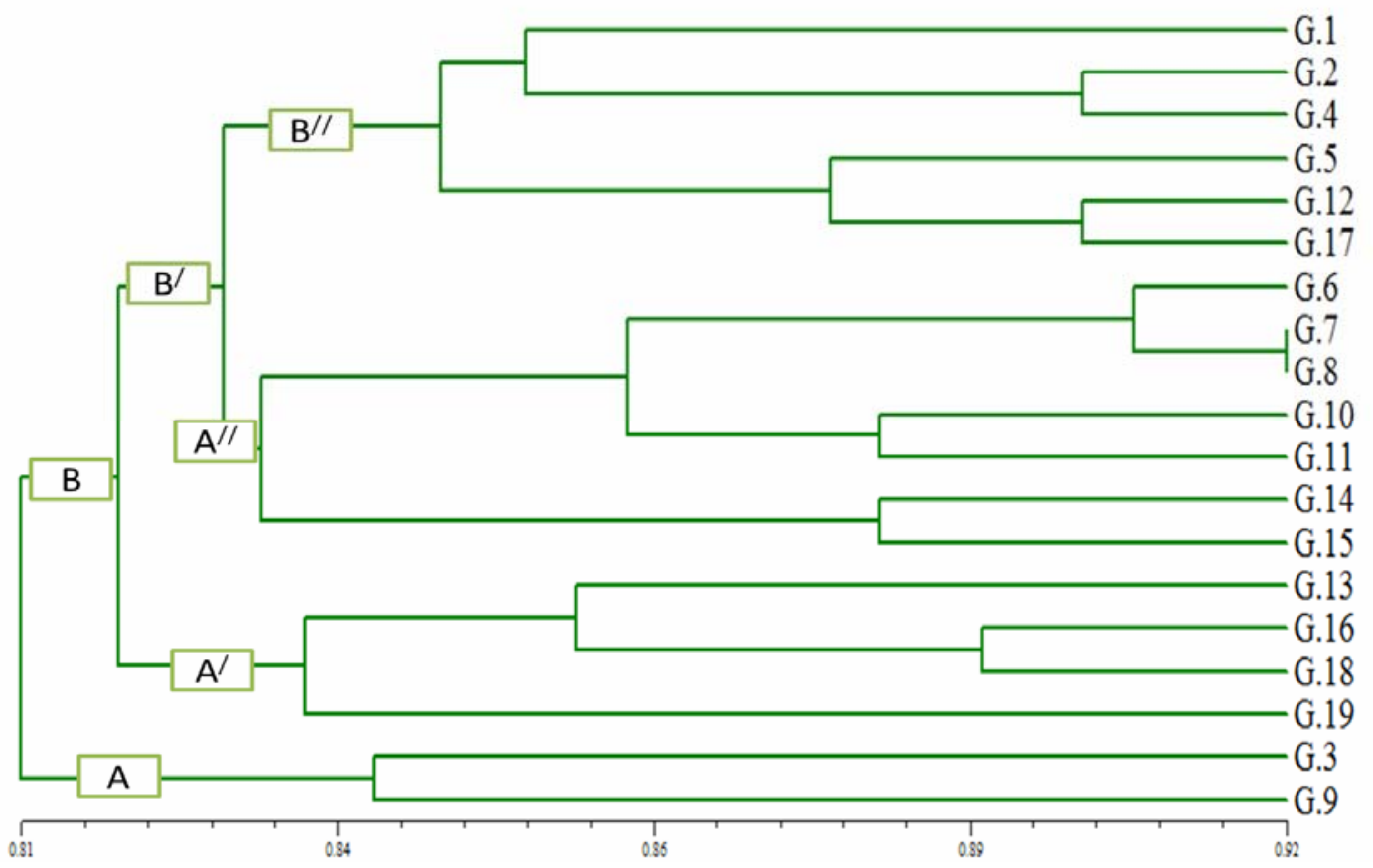

Figure 3. Dendrogram of similiratiy of different ninteen Stevia genotypes based on 8 RAPDRCR primers

\section{REFERENCES}

Abdullateef, R.A., and M. Osman. 2011. Influence of Genetic Variation on Morphological Diversity in Accessions of Stevia rebaudiana Bertoni. Int. J. Biol. 3: 66-72.

Abou-Arab, A.E., A.A. Abou-Arab, and M.F. Abu-Salem. 2010. Physico-chemical assessment of natural sweeteners steviosides produced from Stevia rebaudiana Bertoni plant. Afr. Food Sci. 5: 269- 281.

Ahmad, N., H. Fazal, B. Abbasi, and S. Farooq. 2010. Efficient free radical scavenging activity of Ginkgo biloba, Stevia rebaudiana and Parthenium hysterophorous leaves through DPPH (2,2-diphenyl-1-picrylhydrazyl). Int. Phytom. 3: 231-239.
Amzad-Hossain, M., A. Siddique, and S. Mizanur-Rahman. 2010. Chemical composition of the essential oils of Stevia rebaudiana Bertoni leaves. Asian . Trad. Medicines 2: 5661.

Barriocanal, L., M. Palacios, G. Benitez, S. Benitez, S.J.T. Jimenez, and N. Jimenez. 2008. Apparent lack of pharmacological effect of steviol glycosides used as sweeteners in humans, a pilot study of repeated exposures in some normatensive and hypotensive individuals and in type 1 and type 2 diabetics. J. Regu. Toxicol. and Pharm. 1: 37-41.

Benzie, I.F., and S. Watchel-Galor. 2011. Herbal Medicine: Biomolecular and Clinical Aspects. J. CRC Press, USA. 465: 1-48. 
Brandle, J.E., and N. Rosa. 1992. Heritability for yield, leafstem ratio and stevioside content estimated from a landrace cultivar of Stevia rebaudiana. Can. J. Plant. Sci. 4: $1263-1266$

Chester, K., E.T.Tamboli, R. Parveen, and S. Ahmad. 2013. Genetic and metabolic diveristy in Stevia rebaudiana using RAPD and HPTLC analysis. Pharm. Biol. 6: 771777.

Chikkaswamy, B.K. 2015. Assessment of Genetic Diversity and Relationships of Medicinal Plants using RAPD Marker. Int. Adv. Res. in IT and Eng. 2: 25-35.

Edeoga, H., D. Okwu, and B. Mbaebie. 2005. Phytochemical constituents of some Nigerian medicinal plants. Afr. J. Bio. 7: 685-688.

Frederico, A.P., P.M. Ruas, M.A. Marinmorlaes, C.F. Ruas, and J.N. Nakajima. 1996. Chromosome studies in some Stevia (Compositae) species from southern Brazil. Brazilian . Gene. 4: 605-609.

Geuns, J. M.C. 2003. Stevioside. J. Phytochemistry., 5: $913-$ 921.

Geuns, J.M.C. 2000. Safety of Stevia and stevioside. Recent Res. Dev. Phytochem. 4 : 75-88.

Ghanta, S., A. Banerjee, A. Poddar, and S. Chattopadhyay. 2007. Oxidative DNA damage preventive activity and antioxidant potential of Stevia rebaudiana (Bertoni), a natural sweetener. J. Agric. Food Chem. 26:10962-10967.

Goyal, S.S., and R. Goyal. 2010. Stevia (Stevia rebaudiana) a biosweetener: A review. Int. J. of Food Sci . Nutrition 1: $1-10$.

Huang, X-Y., J-F. Fu, and D-L.Di. (2010). Preparative isolation and purification of steviol glycosides from Stevia rebaudianaBertoni using high-speed counter-current chromatography.J. Sep. and Pur. Technol. 2: 220-224.

Huang, S.Y.G., G. Ai , Y. Q. Cheng, Y. L. Gu, and F. Hong. 1995. Studies on the variation of steviosides content and selection of type R-A in Stevia rebaudiana. J.Plant Res. \& Env. 3: 28-32.

Irwin, S. V., P. Kaufusi, K. Banks, R. D.L. Pena, and J. J. Cho. 1998. Molecular characterization of taro (Colocasia esculenta) using RAPD markers. Journal of Euphytica . 3:183-189.

Kassahunt, B.M., H. Nurhusain, H. Gebremeskel, S.A. Mekonnen, Z. Damtew, M. Philipos, B. Melka, and T. Niide. 2013. Participatory Development of Quality Seedlings for Stevia(Stevia rebaudianaBertoni) Using Stem CuttingsWorld Journal of Agricultural Sciences. 2: 148-154.

Keil, M., and R.A. Griffith. 1994. Use of random amplified polymorphic DNA (RAPD) markers in the discrimination and verification of genotypes in Eucalyptus. Journal of Theoratical and Applied Genetics. 4: 442-450.

khatab, A. 2015. Peroxidase Isozymes and Proline Content In Relation To Salinity Tolerance in Stevia Plant. Alex. Science Exchange J. 3: 206-212.
Kim, I., M. Yang, O. Lee, and S. Kang. 2011. The antioxidant activity and the bioactive compound content of Stevia rebaudiana water extracts. LWT - Journal of Food Science and Technology 5: 1328-1332.

Kroyer, G. 2010. Stevioside and Stevia-sweetener in food: application, stability and interaction with food ingredients. Journal für Verbraucherschutz und Lebensmittelsicherheit. 2: $225-229$.

Lashermes, P., P. Trouslot, F. Anthony, M.C. Combes, and A. Charrier. 1996. Genetic diversity for RAPD markers between cultivated and wild accessions of Coffea arabica.Journal of Euphytica. 1:59-64.

Lavi, V., M. Akkaya, A. Bhagwat, E. Lahav, and P.B. Cregan. 1994. Methodology of generation and characteristics of SSR DNA repeat in Avocado (Persea americana M.).Euphytica. 3: 171-177.

Mahmud, S., S. Akter, I.A. Jahan, S. Khan, A. Khaleque, and S. Islam. 2014. Comparative analyses of stevioside between fresh leaves and in-vitro derived callus tissue from Stevia rebaudiana Bertoni. using HPLC. Bangladesh Journal of Scientific and Industrial Research. 4: 199-204.

Makapugay, H.C., N.P.D. Nanayakkara, and A.D. Kinghorn. 1984. Improved high-performance liquid chromatographic separation of the Stevia rebaudianas weetditerpene glycosides using linear gradient elution.Journal of ChromatographyA. C: 390-395.

Martin, G.B., J.G.K. Williams, and S.D. Tanksley. 1991. Rapid identification of markers linked to a Pseudomonas resistance gene in tomato by using random primers and near isogenic lines. Proceedings of the National Academy of Sciences of the United States of America. 6: 23362340 .

Michelmore, R.W., I. Paran, R.V. Kesseli. 1991. Identification of markers linked to diseaseresistance genes by bulked segregant analysis: a rapid method to detect markers in specific genomic regions by using segregating populations. Proceedings of the National Academy of Sciences of the United States of America. 21: 9828-9832.

Midmore, J.D. and A.H. Rank. 2006. An intense natural sweetener-laying the ground work for a new rural industry. Joural of RIRDC Publication . 6: 1-20.

Mishra, P., R. Singh, U. Kumar, and V. Prakash. 2010. Stevia rebaudiana - A magical sweetener. Global Journal of Biotechenology and Biochemstery. 1: 62-74.

Moktaduzzaman, M., and S.M.M. Rahman. 2009. Regeneration of stevia rebaudiana and Analysis of Somaclonal Variation by RAPD. Journal of Biotechnology. 4: 449-445.

Murray, M.G., and W.F. Thompson. 1980. Rapid isolation of high molecular weight plant DNA. Nucleic Acids Res 8: 4321-4325.

Nishyama, P., M. Alvarez, and L.G.E. Vieira. 1992. Quantitative analysis of stevioside in the leaves of Stevia rebaudianaby near infrared reflectance spectroscopy. Journal of Science Foodand Agriculture. 3: 277-281. 
Oliveira1, D.M.V., E.R. Forni-Martins, P.M. Magalhaes, and M. N. Alves. 2004. Chromosomal and morphological studies of diploid and polyploidcytotypes of Steviarebaudiana (Bertoni) Bertoni (Eupatorieae, Asteraceae). Journal of Genetics and Molecular Biology. 2: 215-222.

Paramanik, R.C., and B.K. Chikkaswamy. 2014. Study on Genetic Diversity relationship some Medicinal plantsusing RAPD Molecular marker. International Journal of Current. Microbiology and Applied Science. 6: 1004-1015.

Pillay, M., and S.T. Kenny. 1996. Structure and inheritance of ribosomal DNA variants in cultivated and wild hop, Humulus lupulus L. Journal of Theoretical and Applied Genetics. 3:333-340.

Puri, M., D. Sharma, and A.K. Tiwari. 2011. Downstream processing of stevioside and its potential applications. Journal of Biotechnology Advances. 6: 781-791.

Radhika, K., S. Sumer, S.M. Gopinath, and A.G.M. Patil. 2012. A study on assessement of genetic diversity and relationships of medicinal plants using RAPD .Global Journal of Research on Medicinal Plants and Indigenous Medicine. 12: 678-686.

Raymond, K.W. 2009. General Organic and Biological Chemistry. Journal of John Wiley \& Sons, USA. 16: 364368.

Reiter, R.S., J.G.K. Williams., K.A. Feldman., J.A. Rafalski., S.V. Tingey, and P.A. Scolnik.(1992). Global and local genome mapping in Arabidopsis thaliana by using recombinant inbred lines and random amplified polymorphic DNAs. Proceedings of the National Academy of Sciences. 4: 1477-1481.

Rohlf, F.J. 2000. On the use of shape spaces to compare morphometric method. Hystrix,The Italian Journal of Mammology (n.s.). 1: 8-24.

Savita, S.M., K. Sheela, A.G.S. Sharan Sunanda, and P. Ramakrishna. 2004. Stevia rebaudiana - A Functional Component for Food Industry.Journal of Human and Ecology. 4: 261-264.
Seema, T. 2010. Stevia rebaudiana: A medicinal and nutraceutical plant and sweet gold for diabetic patients, International Journal of Pharmacy and Life Sciences. 8: 451-457.

Shibata, H., Y. Sawa, T. Oka, S. Sonoke, K. K. Kim, and M. Yoshioka. 1995. Steviol and steviol-glycoside: Glucosyltransferase activities in Stevia rebaudiana Bertoni-Purification and partial characterization. Journal of Archives of Biochemistry and Biophysics. 2: 390-396.

Shukla, S., A. Mehta, V. Bajpai, and S. Shukla. 2009. In vitro antioxidant activity and total phenolic content of ethanolic leaf extract of Stevia rebaudiana Bertoni. Journal of Food and Chemical Toxicology. 9: 2338-2343.

Skoog, D.A., M.D. West, and J. F. Holler. 1988. Fundamentals of Analytical Chemistry (High Performance Liquid Chromatography).Journal of Analytical Ceemistry. 6: $1-15$.

Sun, Q. N., Z. Litu, J. Gao, and T. Huang. 1998. Genetic relationships and diversity among Tibelian whets, common wheat and European spelt wheat revealed by RAPD markers. Journal of Euphytica. 3: 205 - 211.

Thiyagarajan, M., and P. Venkatachalam. 2015. Assessment of genetic and biochemical diversity of Stevia rebaudiana Bertoni by DNA fingerprinting and HPLC analysis. Journal of Annals of Phytomedicine. 1: 79-85.

Thomas, J. E and J. M. Glade (2010). Stevia: It's not just about calories. The Open Obesity Journal. (2): 101-109.

Williams, J.G., R.A. Kubelik, J.K. Livak, K,A.J. Rafalski, and V.S. Tingey. 1990. DNA polymorphisms amplified by arbitrary primers are useful as genetic markers Journal of Nucleic acids research. 22: 6531-6535.

Zaidan, L.B.P., S.M.C. Dietrich, and G.M. Felippe. (1980). Effect of photoperiod on flowering and stevioside content in plants of Stevia rebaudiana Bertoni. Japanase Journal of Crop Science. 49: 569-574. 


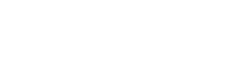

\section{النهسين الوراثيمن خلال الانتخلب لترلكيب وراثيةمختلفة لنبلت الستيفيا}

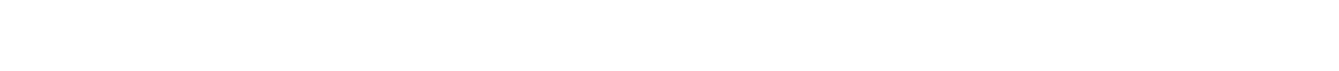

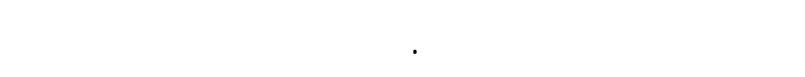

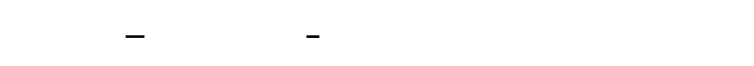

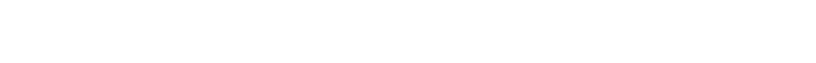
الإبد كندرية ومهط ـة البح -وث الزراعي ــة (ال ـصبحية)

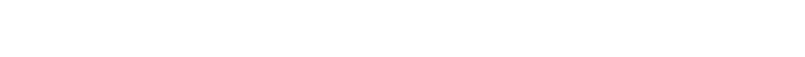

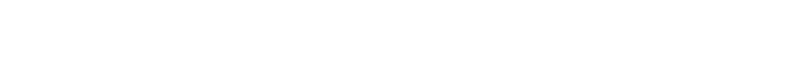

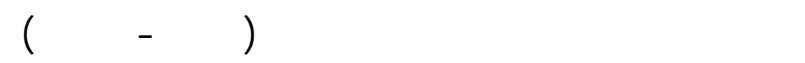

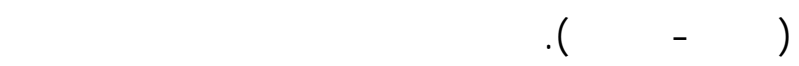

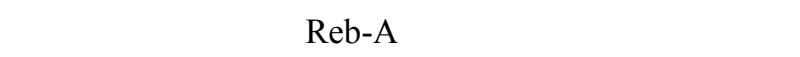

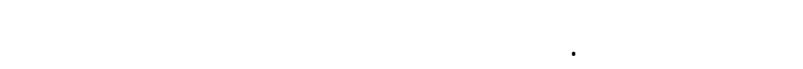

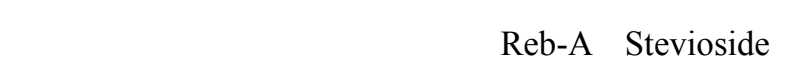

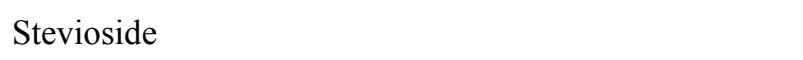

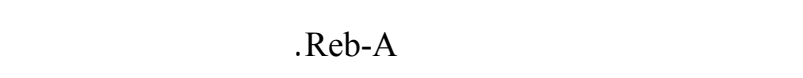

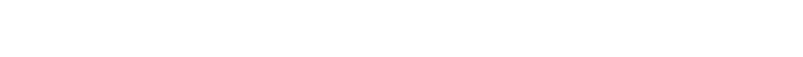
تعدد الششكل المظهرية ان هنك لختلاف كبير فى الـ ششل المنل

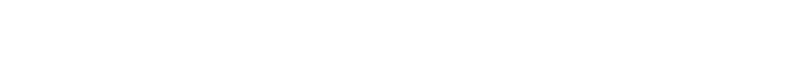
فـ برلمج التربية المسنقبلية.

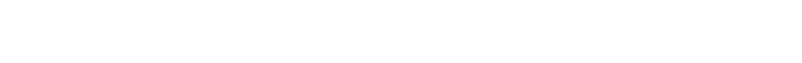

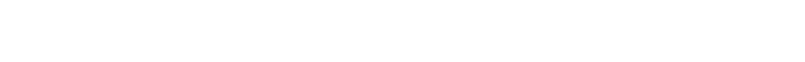
خلال درلمة الخصائص المورفولوجية للترلكيب الوراثي.

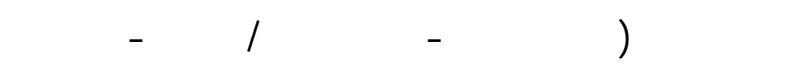

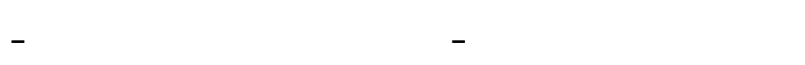

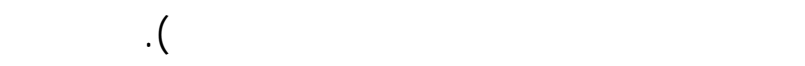

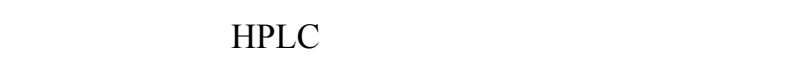

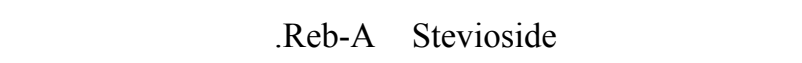

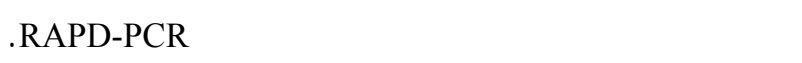
وذك لقدير الاختلاف الوراث بين هذه الأص نالف وم دى الف 